\title{
Identifying the determinants of individual scientific performance: A perspective focused on AMO theory
}

\author{
Felix Guerrero Alba(iD), Fernando Martin Alcazar(iD), Gonzalo Sanchez Gardey (iD) \\ Universidad de Cádiz. (Spain) \\ felix.guerrero@uca.es,fernando.martin@uca.es,gonzalo.sanchez@uca.es
}

Received May, 2020

Accepted August, 2021

\begin{abstract}
Purpose: The aim of this study is to empirically analyse how motivation and the opportunity to investigate enhance the direct relation between the researcher's human capital and individual scientific performance.
\end{abstract}

Design/methodology: Following recent investigations of strategic human capital and the abilitiesmotivation-opportunity (AMO) theory, we propose a double quantitative-qualitative methodology to identify the determinants of individual scientific performance.

Findings: Applying regression analysis to a sample of 471 Spanish academic researchers, we confirm the moderating role of a researcher's motivation and opportunities.

Originality/value: Drawing on the empirical evidence obtained, this work discusses the relevant determinants of scientific productivity, providing practical recommendations for research management and policy making.

Keywords: Academic Human capital, Researcher, AMO theory, DEA, Individual scientific performance

Jel Codes: M10, M12, J24, O15

\section{To cite this article:}

Guerrero Alba, F., Martin Alcazar, F., \& Sanchez Gardey, G. (2021). Identifying the determinants of individual scientific performance: A perspective focused on AMO theory. Intangible Capital, 17(2), 124-147. https://doi.org/10.3926/ic.1654

\section{Introduction}

While direct funding from the government remains the predominant source of university research funding, in recent decades, it has been losing prominence in favour of external funds (Auranen \& Nieminen, 2010). It is generally assumed that academic research productivity and efficiency are linked to external competitive incentives by fundraising (Gonzalez-Brambila \& Veloso, 2007). Since scientific productivity determines the allocation of funds and drives success in academic careers, the researchers have tried to identify those factors that could help to explain individual research performance. Some studies have analysed factors such as gender (Turner \& Mairesse, 2003), age (Rorstad \& Aknes, 2015; Wollersheim, Lenz, Welpe \& Spörrle, 2015), education 
(Buchmueller, Dominitz \& Hansen, 1999) or individual membership in highly productive academic cohorts (Kwiek, 2016), with mixed results (Gonzalez-Bambrila \& Veloso, 2007).

The application of approaches that contextualize the determinants of academic researcher performance becomes necessary to design more efficient research management policies (Diem \& Wolter, 2013; Hedjazi \& Behravan, 2011; Bazeley, 2010; Dundar \& Lewis, 1998). In this context, abilities-motivation-opportunity (AMO) theory has emerged as a suitable approach to evaluate employee performance by differentiating between its key factors (Marin-Garcia \& Martinez Tomas, 2016; Jiang, Lepak, Hu \& Baer, 2012). AMO theory considers that individual performance depends not only on individuals' abilities and job-related motivation, but also on the opportunities offered by their universities and immediate surrounding environment (sectorial technology centres, business foundations, research and development institutes, etc.). AMO theory has been applied by a large number of papers in the organizational context (Van Waeyenber \& Decramer, 2018; Benet-Zepf, Marin-Garcia \& Küster, 2018; Bos-Nehles, Van Riemsdijk \& Kees-Looise, 2013); however, to our knowledge, there are few studies in the educational context (Bouwmans, Runhaar, Wesselink \& Mulder, 2019; Runhaar, 2017; Wollersheim et al., 2015), and none of them explore these variables in the academic research context. Some studies indicate a developing understanding of how context impacts these relationships (Johns, 2017). In summary, the behaviour of the AMO variables according to field of research could offer new perspectives to university managers.

This AMO theory-based study contributes to the literature to better understand the factors that explain individual scientific performance in the context of academic institutions. Based on a review of the existing literature and application of a double quantitative-qualitative methodology, a set of AMO elements was defined and analysed. The study is organized as follows. After this introduction, we review the literature and propose a model where individual scientific performance is linked to the three AMO elements by defining three hypotheses. We propose a double quantitative-qualitative methodology to identify the determinants of individual scientific performance. Then, the process of data gathering and analysis, based on a sample of 471 Spanish researchers, is explained in detail. Accordingly, four regression models have been developed with the goal of contrasting the proposed hypotheses. The last section explains the conclusions and limitations of this study and identifies possible future lines of research.

\section{Theoretical framework and hypotheses}

Researchers have put great effort into analysing the link between individual employee effort and individual performance (Wright \& McMahan, 2011). In this context, AMO theory suggests that an individual's discretionary effort is conditioned by the ability, motivation and opportunity to participate (Appelbaum, Bailey, Berg \& Kallenberg, 2000). The role of these elements in individual performance has been explored by authors such as Beltrán-Martín and Bou-Llusar (2018) and Wang and Xu (2017). However, it is necessary to further investigate their relevance in different organizational contexts (Van Waeyenber \& Decramer, 2018; Knies \& Leisink, 2014). In the next sections, we explore the impact of AMO elements in the research academic context, with the objective of defining hypotheses for the relationships specified in the proposed AMO models. Only research ability, we argue, has an independent, direct, and positive effect on scientific performance, and this effect could be positively or negatively influenced by motivation and opportunity. Researcher ability is defined as the research knowledge, skills and abilities of academic researchers necessary for scientific performance. Researcher motivation represents the desire and willingness to scientific performance. Finally, researchers' abilities are involved in decisions that impact scientific performance when they are given the opportunity to do so. In the next sections, we review what is known about researchers' abilities, motivation and opportunities.

\subsection{Research abilities: Academic human capital perspective}

The literature has identified the first dimension of the AMO approach as human capital, defined as the set of knowledge, skills and abilities (KSA) that enables an individual to carry out a particular activity in a specific context (Kim, Pathak \& Werner, 2015; Jiang et al., 2012). The scientific literature has not reached a consensus on which human capital-specific attributes enable academics to carry out research activities (Durette, Fournier \& Lafon, 2016; McNie, Parris \& Sarewitz, 2016; Thunnissen \& Van Arensbergen, 2015). 
Generally, knowledge has been classified by researchers into two types: tacit and explicit (Nonaka \& Takeuchi, 1995). Tacit knowledge refers to formal knowledge associated with the procedures, routines or ideas acquired through specific training received during academic studies (Horta \& Santos, 2016; Su, 2011). This individualbased knowledge is generated as an implicit combination of the acquired cognitive models, experiences, points of view, intuition, etc., that enables individuals to understand the nature of a research topic within a specific field. Therefore, it is composed of both the fundamental theories and assumptions of a specific discipline (Bozeman, Dietz, \& Gaughan, 2001; Lovitts, 2005), as well as the essential and specific elements of a particular research line (Lee, Miozzo \& Laredo, 2010).

Second, existing studies considered explicit knowledge as the knowledge stored in various knowledge repositories, such as books, research dissertations, academic journals, and databases, which are available to future researchers (Rowley, 2000; Tiam, Nakamori \& Wierzbicki, 2009; Prpić, 1996). In this case, such knowledge is perfectly coded in a systematized language that can be easily transmissible between academic researchers.

The literature does not show a clear differentiation between scientific skills and scientific abilities. Some authors have characterized scientific skills as general personal attributes applicable to different types of jobs, such as vocation to work (Bentley \& Kyvik, 2013), creativity (Marie, 2008) or professional ethics (Bell \& Bryman, 2007). From this point of view, academic skills can be understood as those individual capabilities related to the execution of a single task. Conversely, scientific abilities are composed of job attributes more specific to research, such as the capacity to identify research topics (Ulrich \& Dash, 2013), the capacity to communicate research outcomes (Thunnissen \& Van Arensbergen, 2015) or the capacity to formulate bypotheses and collect data (Marie, 2008). In this sense, scientific abilities are defined as individual capabilities that foster adequate research performance.

Figure 1 summarizes this conceptualization of research abilities.

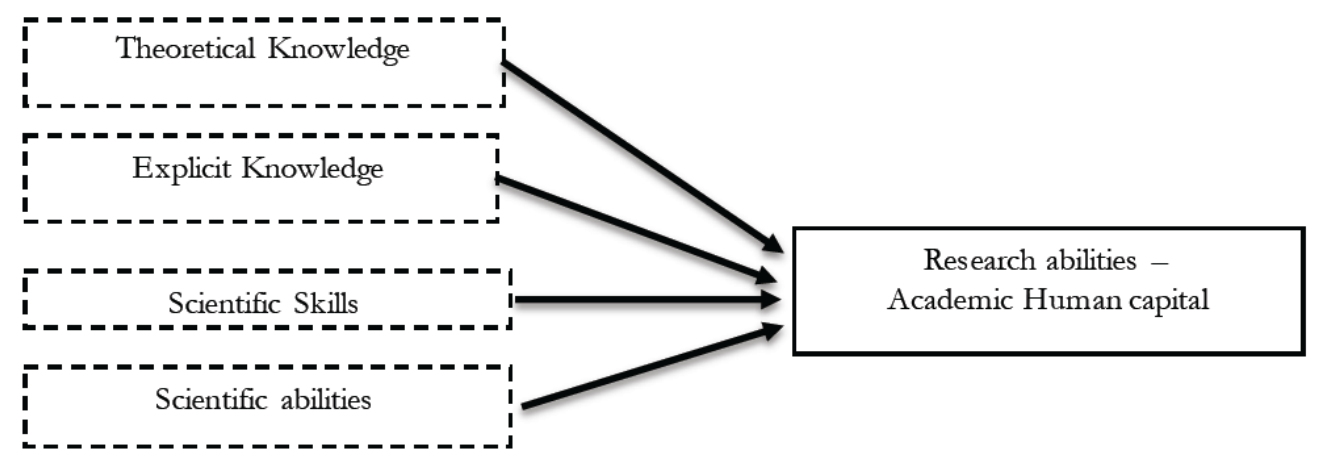

Figure 1. Theoretical research model for researcher abilities

Different studies have confirmed the positive influence of human capital on performance (Wright, Coff \& Moliterno, 2014; Harris, McMahan \& Wright, 2012; Coff \& Kryscynski, 2011). For this purpose, they have argued that the stock of aggregated human capital helps to generate sustainable competitive advantages (Ployhart \& Moliterno, 2011). According to the above arguments, it seems clear that human capital is essential for research. Based on the above, we propose the following hypothesis to determine the composition of human capital in the academic field:

Hypothesis 1: There is a direct and positive relationship between a researcher's abilities (academic buman capital) and individual scientific performance.

Hypothesis 1a: There is a direct and positive relationship between theoretical knowledge and individual scientific performance. 
Hypothesis 1b: There is a direct and positive relationship between explicit knowledge and individual scientific performance.

Hypothesis 1c: There is a direct and positive relationship between scientific skills and individual scientific performance.

Hypothesis 1d: There is a direct and positive relationship between scientific abilities and individual scientific performance.

This direct relation between human capital and individual scientific performance will be used as a starting point to examine the effect of the other two AMO theory dimensions: motivation and opportunity. These two dimensions are studied as moderating variables of the main and direct relation. The moderation effects will be explained in the next section.

\subsection{The moderating dimensions: Motivation and opportunity}

Human capital (abilities) is a necessary condition for a researcher to carry out his or her activity. An additional element is required, which is the will to conduct research. Motivation is the trigger that activates researchers' human capital (Bos-Nehles et al., 2013). Motivation is defined as the desire and the amount of effort that people are willing to put into a particular activity (Mitchell, 1982). Individual motivation, or absence of it, can inhibit, encourage or compensate for the knowledge and/or abilities of an individual (MacDuffie, 1995). Within the academic field, this factor encourages the researcher to explore, understand and propose his or her own ideas in the scientific field, thereby generating new knowledge (Bland, Center, Finstad, Risbey \& Staples, 2005).

The literature on motivation has identified two classic types of motivation: internal or intrinsic motivation and external or extrinsic motivation (Wollersheim et al., 2015; Deemer, Martens \& Buboltz, 2010). Intrinsic motivation is related to the level of involvement and identification of the individual with his/her job. It is thereby determined by the extent to which the researcher considers his or her research activity to be relevant, stimulating and challenging (Van der Weijden, Belder, Van Arensbergen \& Van den Besselaar, 2015). Extrinsic motivation, on the other hand, is associated with individual interests and values that enable the design of reward and promotion systems linked as much to the development of the activity as to personal acknowledgement (Peng \& Gao, 2019). For researchers, the literature considers a set of mechanisms such as academic career promotion (Tien, 2008), salary increases or teaching workload reduction based on academic performance (Lissoni, Mairesse, Montobbio \& Pezzoni, 2011).

In the university sector, studies have analysed the joint effects of researchers' intrinsic and extrinsic motivation and reported inconclusive conclusions (Janger \& Nowotny, 2016; Hardre \& Kollmann, 2012). Some studies, such as those by Shmatko and Volkova (2017) or Kwiek (2016), concluded that intrinsic motivation has a more positive contribution than extrinsic motivation because of the resulting satisfaction associated with carrying out research activity. Fox (1983) found that researchers' intrinsic motivation may compensate for the absence of external motivation. As Lovitts (2005) pointed out, those researchers who have enough autonomy to define and carry out their research projects are more internally motivated because of the satisfaction of developing research studies that are actually appealing to them (Chen, Gupta \& Hoshower, 2006).

Considering previous arguments, we expect that intrinsic and extrinsic motivation contribute to the satisfaction, professional prestige and reward of researchers. In short, we summarize researcher motivation in Figure 2.

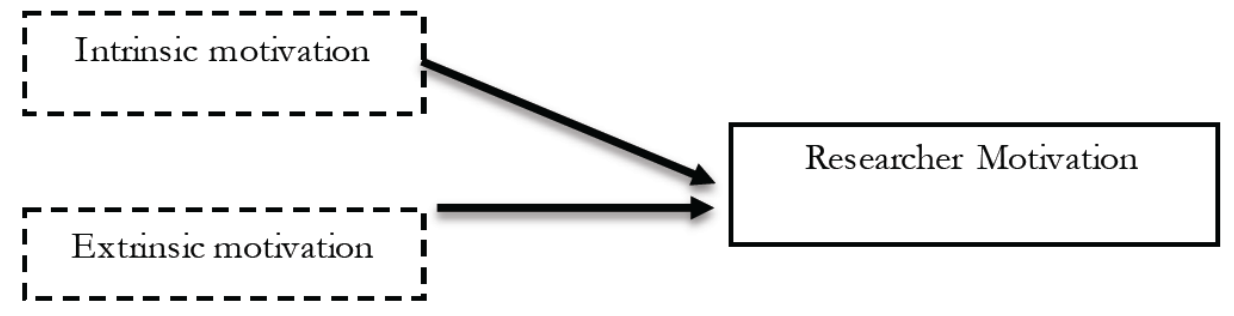

Figure 2. Theoretical research model for researcher motivation 
Thus, we propose the following hypotheses in the research context:

Hypothesis 2: The positive effect of a researcher's abilities (academic buman capital) on individual scientific performance increases as the researcher's motivation increases.

Hypothesis 2a: The positive effect of a researcher's abilities (academic buman capital) on individual scientific performance increases as the researcher's intrinsic motivation increases.

Hypothesis 2b: The positive effect of a researcher's abilities (academic human capital) on individual scientific performance increases as the researcher's extrinsic motivation increases.

Existing research points out that even when employees have the ability and motivation to perform their jobs, there might be no effect on performance if the organization does not provide the necessary resources (Lepak, Liao, Chung \& Harden, 2006; Jiang et al., 2012). An opportunity represents the contextual mechanisms that encourage action, such as the work environment and organizational facilities (Boxall \& Purcell, 2003; Siemsen, Roth \& Balasubramanian, 2008). This dimension includes those elements that facilitate or restrict job execution, such as the particular configuration of the environment surrounding the employee (Blumberg \& Pringle, 1982). The literature has identified three basic categories of resources for research: financial funds, availability of qualified human resources, and physical and digital resources (Agasisti, Catalano, Landoni \& Verganti, 2012; Agasisti, Dal Bianco, Landoni, Sala \& Salerno, 2011; Schuelke-Leech, 2013). Financial funds, although showing noticeable differences by the field of knowledge, have traditionally been considered one the main resources for research (Hicks, 2012). Some studies propose that the concentration of financial funds allows greater research results to be achieved (Lariviere, Macaluso, Archambault \& Gingras, 2010; Zucker, Darby, Furner, Liu \& Ma, 2007).

The literature has also explored the availability of qualified buman resources in the research context. Some authors have proposed that individual research productivity is conditioned by the researcher life cycle (GonzalezBrambila and Veloso, 2007). Such studies suggest that scientific production is highly concentrated within only a few senior researchers (Kwick, 2016). Nonetheless, inasmuch as scientific research activities are currently mainly a question of collaboration within a team, the availability of qualified human resources appears to be a question of balance in team composition. If senior researchers are responsible for providing the human and material resources needed to foster research activity (Carayol \& Matt, 2004; Delamont, Atkinson \& Parry, 1997), junior researchers should support research activities, allowing senior researchers to improve the team's intellectual resources, which leads to new knowledge and skills in scientific performance (White, James, Burke \& Allen, 2012). Furthermore, an experienced researcher is key to improving the psychosocial working conditions of $\mathrm{PhD}$ students, increasing the number of successful $\mathrm{PhD}$ candidates and research group performance (Levecque, Ansell, De Beuckelaer, Van der Heyden \& Gisle, 2017; Nguyen, 2016; Curtin, Malley \& Stewart, 2016). Last, senior researchers must ensure that support staff help academic researchers focus on research activity and increase their time devoted to research (Mudrak et al, 2018; Nguyen, 2016; Barham, Foltz \& Prager, 2014).

Finally, academic research requires the availability of physical resources (space, infrastructure and equipment) as well as the availability of digital resources (databases, scientific and statistical software) (Schuelke-Leech, 2013). Access to specialized equipment and academic knowledge, among other resources, facilitates scientific productivity (Wang, Peters \& Guan, 2006). Within this context, studies such as Käpylä, Jääskeläinen and Lönnqvist, (2010) identify the management and use of ICT as facilitators of scientific productivity as they enable access to the databases necessary for literature reviews. However, this finding contrasts with those of other studies, such as the results reported by Agasisti et al. (2011), which were not consistent when contrasting the effect of infrastructure and the research efficiency of different departments.

In short, we summarize the conceptualization of research opportunities in Figure 3. 


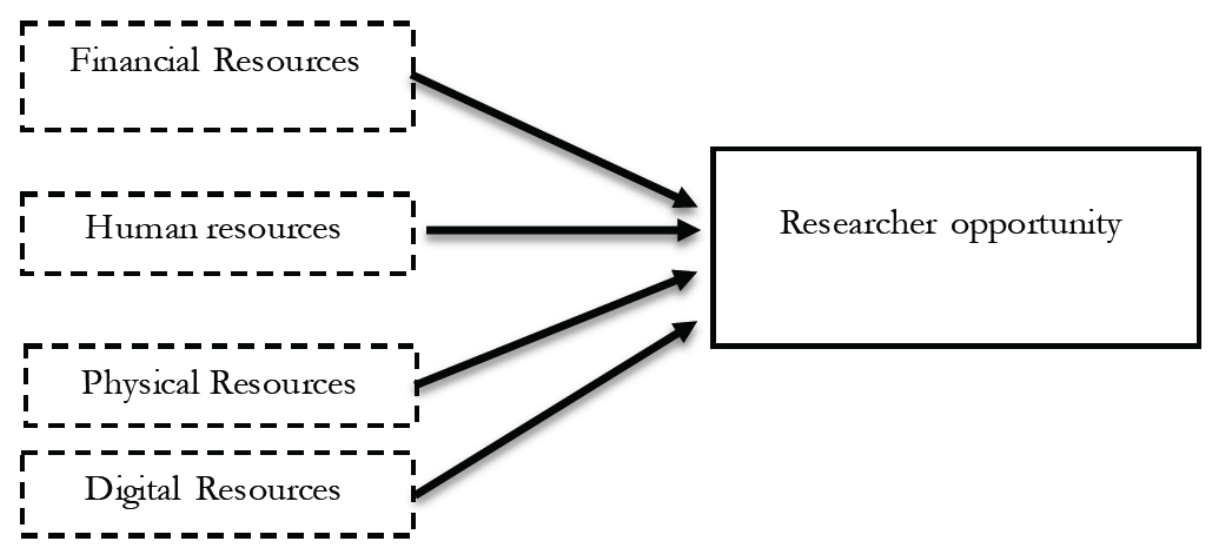

Figure 3. Theoretical research model for researcher opportunities

The literature review suggests that opportunity conditions the relationship between academic human capital (researcher abilities) and individual scientific performance. Different classic frameworks, such as the jobdemands-control model, have considered the multiplicative effects between the abilities and opportunities dimensions (Karasek, 1979). Consequently, our model suggests that opportunities are necessary to promote researchers' abilities and scientific performance. Therefore, we propose the following hypotheses:

Hypothesis 3: The positive effect of a researchers' abilities (academic buman capital) on individual scientific performance is bigher as the researcher's opportunities increase.

Hypothesis 3a: The positive effect of a researcher's abilities (academic buman capital) on individual scientific performance increases as the availability of financial resources increases.

Hypothesis 3b: The positive effect of a researcher's abilities (academic human capital) on individual scientific performance increases as the availability of qualified human resources increases.

Hypothesis 3c: The positive effect of a researcher's abilities (academic buman capital) on individual scientific performance increases as the availability of physical resources increases.

Hypothesis $3 d$ : The positive effect of a researcher's abilities (academic buman capital) on individual scientific performance increases as the availability of digital resources increases.

Figure 4 shows the theoretical model proposed based on the AMO approach for the academic context.

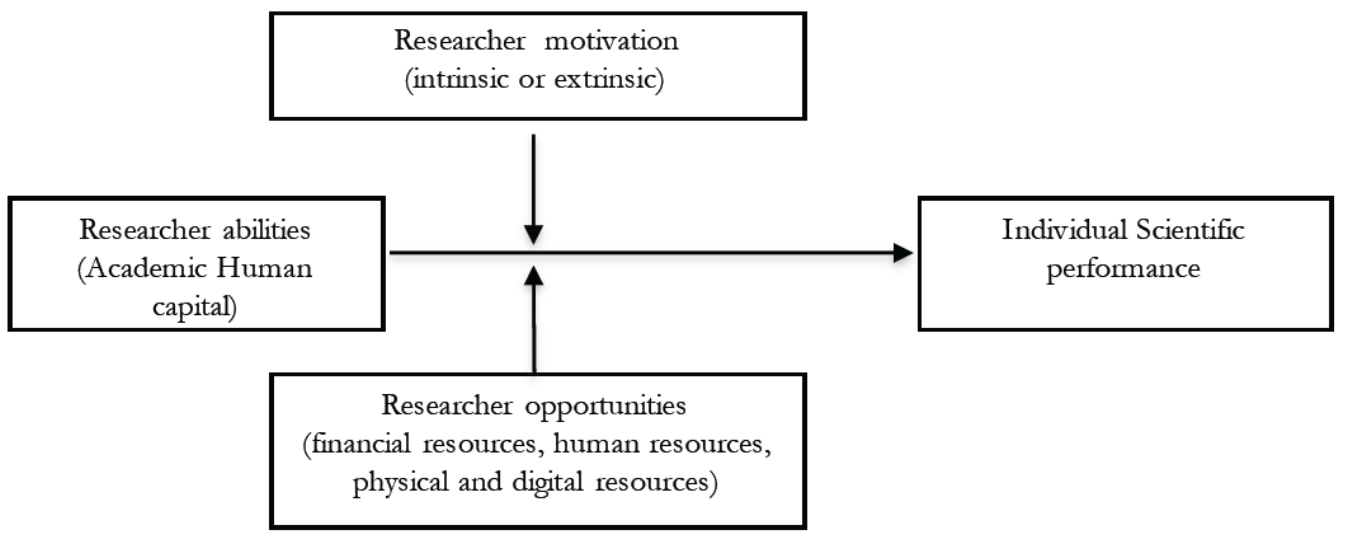

Figure 4. Theoretical research model for the effectiveness of academic researchers 


\section{Methodology}

\subsection{Survey design}

Since the literature does not offer a validated measurement scale, we considered designing and validating a scale adapted to the research field. For this purpose, a qualitative process was developed based on expert opinion and the Delphi methodology (Landeta, 1999). This methodology offers a systematic and iterative procedure that aims to achieve expert consensus. Experts are informed about the opinions of others with the purpose of reaching consensus (Landeta, 1999). Our expert panel was composed of principal investigators (PIs) from the Plan Andaluz de Investigación (Andalusian Research Plan). They were chosen because of their knowledge and varied experience in the development and management of scientific processes, as well as project and research team management. Experts were selected from the different scientific fields of study to avoid response bias and subjectivity issues resulting from this type of technique (Okoli \& Pawlowski, 2004). The final expert panel was composed of 62 PIs (20 in arts and humanities, 18 in sciences, 8 in health sciences, 6 in law and social sciences and 10 in engineering and architecture). The distribution according to field of study suggests that the studied variables will be similar to those seen in other Spanish universities due to their nature. Also, the criteria used in the Andalusian Research Plan are the same the criteria used in other Spanish universities to define the research groups and their evaluation. In summary, the selected experts have similar characteristics to the research groups from other Spanish universities. Eight open questions were presented to the PIs in order to reach an expert consensus. After three rounds of discussion, the PIs reached consensus. Thirty-six items were identified: 22 items for measuring human capital (abilities), 6 for motivation, and 8 for opportunity. From these, we designed a questionnaire with 36 items on a 5 -point Likert scale $(1=$ completely disagree and $5=$ completely agree), including demographic questions on gender, age, length of academic career, number of six-year period of research positively assessed-sexenio-, academic rank, field of study, and university. Then, a pre-test was conducted among a group of researchers to eliminate any issues in the design and drafting of each item. Prior to the survey, we reduced the ambiguous and unclear items, vague concepts, and complex wording during the expert panel and survey design stages to minimize common method bias (CMB).

\section{Sample description}

Data were gathered through an online survey aimed at researchers from Spanish universities. The fieldwork took place from January-October 2017. The survey was submitted to the research vice-rectorate of Spanish public universities with the request to distribute them among researchers, and a total of 2223 responses were obtained. Considering the nature of our model and dataset, we paid particular attention to controlling for CMB. We developed procedures to control for possible biases based on the recommended studies, such as Conway and Lance (2010) and Podsakoff, MacKenzie, Lee and Podsakoff (2003), which allowed us to conclude that CMB was not a serious concern. From the Harman one-factor test, several factors emerged from each AMO dimension, suggesting that CMB did not significantly affect the empirical analysis (Podsakoff et al., 2003). On the other hand, we studied the partial correlation adjustment in the sample obtained. We defined one marker variable to compare the correlation matrix of the factor variable and correlations adjusted following the indications of Lindell and Whitney (2001) (see Appendix). Our results showed that only one of the significant correlations became non-significant after adjustment. These results demonstrate that CMB did not significantly influence the analyses.

To define the final sample, we kept only individuals who identified themselves by name or ORCID code and who had a permanent position at the university (full professors-"catedráticos", professors-"titulares de universidad" and associate professors- "contratado doctores"). The identification of respondents was necessary to analyse their academic results. Since the identification of researchers could induce social desirability bias in their responses, we placed the items used for identification at the end of the questionnaire.

The final sample consisted of a total of 471 valid responses $(21.19 \%)$, which provided valid and reliable measures of the dimensions treated in the present study. Table 1 presents the sample descriptive statistics. 


\begin{tabular}{|c|c|}
\hline Variable & Descriptive Statistics \\
\hline Gender & $\begin{array}{l}\text { Male: } 65 \% \\
\text { Female: } 35 \%\end{array}$ \\
\hline Age & $\begin{array}{l}>65 \text { years: } 4.8 \% \\
56-65 \text { years: } 26.5 \% \\
46-55 \text { years: } 49.1 \% \\
36-45 \text { years: } 19 \% \\
<35 \text { years: } 0.8 \%\end{array}$ \\
\hline $\begin{array}{l}\text { Length of academic } \\
\text { career }\end{array}$ & $\begin{array}{l}>20 \text { years: } 67.3 \% \\
16-20 \text { years: } 17.2 \% \\
11-15 \text { years: } 10.2 \% \\
5-10 \text { years: } 4.7 \% \\
<5 \text { years: } 0.6 \%\end{array}$ \\
\hline $\begin{array}{l}\text { Number of six-year } \\
\text { period of research } \\
\text { positively assessed } \\
\text { (sexenio) }\end{array}$ & $\begin{array}{l}6: 3.0 \% \\
5: 10.4 \% \\
4: 20.3 \% \\
3: 22.4 \% \\
2: 20.7 \% \\
1: 15.8 \% \\
0: 7.5 \%\end{array}$ \\
\hline Academic rank & $\begin{array}{l}\text { Full Professors (catedráticos): } 31.8 \% \\
\text { Professors (titulares de universidad): } 50.5 \% \\
\text { Associate Professors (contratado doctores): } 17.6 \%\end{array}$ \\
\hline Field of study & $\begin{array}{l}\text { Art \& Humanities: } 15.1 \% \\
\text { Sciences: } 37.7 \% \\
\text { Health Sciences: } 8.1 \% \\
\text { Law \& Social Sciences: } 23 \% \\
\text { Engineering \& Architecture: } 16.2 \%\end{array}$ \\
\hline University & $\begin{array}{l}\text { University of Oviedo: } 9.6 \% \\
\text { University of Valladolid: } 8.5 \% \\
\text { University Politécnica de Madrid: } 7.9 \% \\
\text { University of Las Palmas de Gran Canaria: } 7 \% \\
\text { University of Málaga: } 6,8 \% \\
\text { University Complutense de Madrid: } 5.3 \% \\
\text { University of Sevilla: } 4.5 \% \\
\text { University of Alcalá: } 3.8 \% \\
\text { University of Alicante: } 3.8 \% \\
\text { University of León: } 3.4 \% \\
\text { University of Zaragoza: } 3.4 \% \\
\text { University of Cantabria: } 3 \% \\
\text { University of Barcelona: } 2,8 \% \\
\text { University of Granada: } 2.8 \% \\
\text { University of La Laguna: } 2.5 \% \\
\text { University Politécnica de Valencia: } 2.5 \% \\
\text { University of Vigo: } 2.3 \% \\
\text { University Autónoma de Madrid: } 2.1 \% \\
\text { University of Coruña: } 1.9 \% \\
\text { University of País Vasco: } 1.9 \% \\
\text { University of Valencia: } 1.9 \% \\
\text { University of Vic: } 1.7 \% \\
\text { University Politécnica de Cataluña: } 1.5 \% \\
\text { University Autónoma de Barcelona: } 1.3 \% \\
\text { University of Burgos: } 1.3 \% \\
\text { University of Córdoba: } 1.3 \% \\
\text { University of Girona: } 1.3 \% \\
\text { University of Almería: } 0.6 \% \\
\text { University Politécnica de Cartagena: } 0.6 \% \\
\text { University Rey Juan Carlos: } 0.6 \% \\
\text { University of Salamanca: } 0.6 \% \\
\text { University Carlos III: } 0.4 \% \\
\text { University Pompeu Fabra: } 0.4 \% \\
\text { University of Castilla La Mancha: } 0.2 \% \\
\text { University of IE University: } 0.2 \% \\
\text { University Ramón Llull: } 0.2 \% \\
\end{array}$ \\
\hline
\end{tabular}

Table 1. Descriptive statistics $(n=471)$ 


\section{Empirical analysis}

\section{Factor Analysis}

First, a factor analysis was conducted to identify the implicit dimensions of the three model components in the data: abilities, motivation and opportunity. The analysis was based on the main components method of extraction, resulting later in a varimax rotated solution. Kaiser-Meyer-Olkin and Bartlett's sphericity tests were performed in the three factor analyses. The decision regarding the number of factors was based on the screen test (Cattell, 1966) and on the eigenvalue selection criterion being superior to the unit (Kaiser, 1974). Those items that did not load adequately on their factor were eliminated, and the test was repeated.

Researcher abilities (Academic Human Capital)

\begin{tabular}{|c|c|c|c|c|c|}
\hline \multirow[t]{2}{*}{ Items } & \multicolumn{5}{|c|}{ Components } \\
\hline & 1 & 2 & 3 & 4 & 5 \\
\hline $\begin{array}{l}\text { I know how to present and communicate my research } \\
\text { findings }\end{array}$ & .831 & & & & \\
\hline I am able to fluently relate to other researchers & .770 & & & & \\
\hline $\begin{array}{l}\text { I know how to manage research activities (thesis, research } \\
\text { projects, etc.) }\end{array}$ & .739 & & & & \\
\hline $\begin{array}{l}\text { I know how to link observations with test results and arrive } \\
\text { at conclusions }\end{array}$ & .703 & & & & \\
\hline I am able to carry out research on my own & .675 & & & & \\
\hline I am able to adapt to changes within my research context & .653 & & & & \\
\hline $\begin{array}{l}\text { I am able to identify research themes within my research } \\
\text { context }\end{array}$ & .635 & & & & \\
\hline $\begin{array}{l}\text { I have the necessary training in research methodologies and } \\
\text { techniques }\end{array}$ & & .732 & & & \\
\hline $\begin{array}{l}\text { I have the necessary theoretical training to conduct research } \\
\text { within my scientific field }\end{array}$ & & .723 & & & \\
\hline $\begin{array}{l}\text { I know the most relevant publications within my scientific } \\
\text { field }\end{array}$ & & .716 & & & \\
\hline $\begin{array}{l}\text { I have the required skill to obtain and manage the } \\
\text { information necessary for research }\end{array}$ & & .677 & & & \\
\hline I am a creative researcher & & & .797 & & \\
\hline I am a researcher who takes initiative & & & .718 & & \\
\hline I am a resilient researcher & & & .626 & & \\
\hline I am a researcher with observation skills & & & .522 & & \\
\hline I am a disciplined researcher & & & & .873 & \\
\hline I am an organized researcher & & & & .838 & \\
\hline I am a persevering researcher & & & & .687 & \\
\hline I am a researcher who accept criticism & & & & & .817 \\
\hline I am a self-critical researcher & & & & & .729 \\
\hline I am an altruistic researcher & & & & & .526 \\
\hline Eigenvalues & 7.042 & 2.251 & 1.370 & 1.338 & 1.091 \\
\hline Explained variance & 33.54 & 10.72 & 6.52 & 6.37 & 5.19 \\
\hline Cronbach's alpha $\quad .884$ & & & & & \\
\hline $\begin{array}{l}\text { Kaiser-Meyer-Olkin Measure of Sampling Adequacy: } \\
\text { Bartlett’s Test of Sphericity: }\end{array}$ & .896 & & & & \\
\hline $\begin{array}{l}\text { Approx. Chi-Square: } \\
\text { gl: } \\
\text { Significance: }\end{array}$ & $\begin{array}{r}010.596 \\
210 \\
.000\end{array}$ & & & & \\
\hline
\end{tabular}

Table 2. Analysis of the main components (varimax rotation) of researcher abilities (academic human capital) $(\mathrm{n}=471)$

For the first dimension (academic human capital), five factors were obtained (Table 2). The item "I master the language usually used in journals/books and in scientific meetings in my academic field" was eliminated from the analysis since it loaded insufficiently onto one factor. The first factor consisted of seven items linked to elements 
associated with the implementation of research activity. Among these items are the ability to communicate research findings, relationship with colleagues and research management. These elements allow a researcher to carry out his or her research and continue to progress adequately in his or her academic career. For this reason, we labelled it "Research abilities". The second factor consisted of four items related to the researcher's level of theoretical training and methodology, his or her ability to find and manage information from publications relevant to his or her field of knowledge, and knowledge of the scientific publications within the research area. Consequently, we labelled it "Scientific knowledge". The third factor consisted of four items related to the researcher's creative perception and his or her initiative in carrying out research activity, so we labelled it "Proactive creativity". The fourth factor consisted of three items related to constancy, discipline and organization in the workplace, labelled "Research accuracy". Finally, the fifth factor consisted of three other items that measured to what extent the researcher accepts criticism and reviews of his or her work. We labelled this factor "skill of accepting criticism".

Researcher motivation

For the second dimension (motivation), two factors were obtained (Table 3). The item "I research for my own personal prestige" was eliminated from the analysis since it loaded insufficiently onto one factor. The first factor consisted of those items related to the researcher's external aspects, such as promotion or achievement of research merits. The second factor consisted of incentives associated with the internal satisfaction of carrying out research activity. Hence, the first factor was labelled "Extrinsic Motivation", and the second factor was labelled "Intrinsic Motivation".

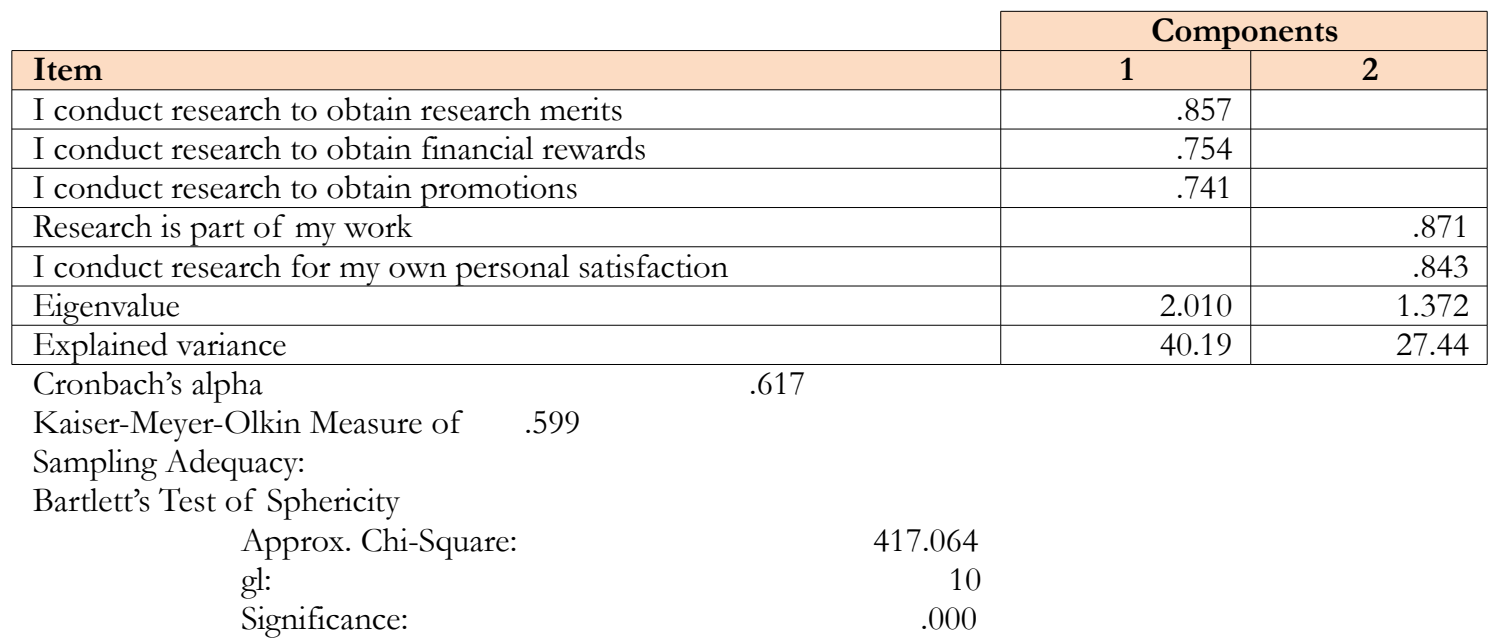

Table 3. Analysis of the main components (varimax rotation) of researcher motivation $(n=471)$

Researcher opportunities

The third dimension (opportunity) consisted of eight items grouped into two factors (Table 4). The first factor includes items that explain the availability of financial and human resources, while the second factor includes items related to the availability of information resources. Therefore, the first one was labelled "Availability of financial and buman resources", and the second one was labelled "Availability of information resources". 


\begin{tabular}{|c|c|c|}
\hline & \multicolumn{2}{|c|}{ Components } \\
\hline Item & 1 & 2 \\
\hline Availability of financial resources & .751 & \\
\hline Availability of experienced researchers & .694 & \\
\hline Availability of researchers in training & .635 & \\
\hline Availability of equipment & .578 & \\
\hline Availability of technical staff & .533 & \\
\hline Availability: Database access & & .760 \\
\hline Availability of software & & .613 \\
\hline Availability of literature resources & & .591 \\
\hline Eigenvalue & 2.609 & 1.205 \\
\hline Explained variance & 32.616 & 15.061 \\
\hline
\end{tabular}

Kaiser-Meyer-Olkin Measure of $\quad .741$

Sampling Adequacy:

Bartlett's Test of Sphericity

$\begin{array}{lr}\text { Approx. Chi-Square: } & 176.433 \\ \text { gl: } & 28 \\ \text { Significance: } & .000\end{array}$

Table 4. Analysis of the main components (varimax rotation) of researcher opportunities $(n=471)$

Additionally, we conducted the AMO dimension test using EQS structural equation modelling (Bentler, 1995) as proof of nomological validity. To test the dimensionality of the academic AMO scale, we first examined the unidimensionality of each component by assessing the fit indices, parameter validity, and statistical significance of single-factor confirmatory factor analyses (CFA). For this, we used all the AMO dimensions for the expert panel and exploratory factor analysis. Our study considered the AMO dimensions as a reflective construct. Table 5 presents the fit indices for each construct (researchers abilities-academic human capital, motivation, and opportunities). Fit indices were also used to verify the unidimensionality of the three scales because they fell within the commonly accepted limits. Therefore, each of the AMO dimensions formed a second-order construct.

\begin{tabular}{|l|r|r|r|r|r|r|}
\hline Model & BBNNFI & CFI & IFI & RMSEA & GFI & AGFI \\
\hline Researcher abilities (Academic human capital) & .949 & .955 & .955 & .061 & .964 & .955 \\
\hline Researcher Motivation & .918 & .975 & .976 & .065 & .998 & .991 \\
\hline Researcher Opportunities & .920 & .949 & .951 & .068 & .982 & .964 \\
\hline
\end{tabular}

Notes: Bentler-Bonnett Non-Normed Fit index (BBNNFI); Comparative fit index (CFI), Incremental Fit Index (IFI); the root mean square error of approximation (RMSEA); the goodness of fit index (GFI); the adjusted goodness of fit index (AGFI).

Table 5. Fit indices for the unidimensional models of researcher abilities (academic human capital), motivation and opportunities dimensions

\section{Regression analysis}

Independent variables:

The five factors associated with researcher's abilities (academic human capital), the two factors associated with motivation and the two factors associated with opportunity were all used as independent variables. Table 6 identifies the correspondence between the hypothesis and factorial analysis. As can be observed in the factorial analysis, the researcher's motivation is the same between the theoretical dimension and factorial analysis, considering extrinsic and intrinsic motivation. However, the researcher's abilities and opportunities showed some differences. In the researcher's abilities, we observed academic human capital, such as the KSA framework, as having three dimensions, while factorial analysis has been established with five dimensions. Surprisingly, research skills differed in three different dimensions: proactive creativity, research accuracy and skill of accepting criticism. Likewise, the knowledge dimension was integrated into a single factor. Similarly, in the opportunity dimension, the availability of 
financial resources and availability of qualified buman resources were integrated into a single factor, and the availability of physical resources and digital resources were also integrated into a single factor.

\begin{tabular}{|l|l|}
\hline Theoretical Dimensions & Factorial analysis dimensions \\
\hline $\begin{array}{l}\text { Theoretical knowledge } \\
\text { Explicit knowledge }\end{array}$ & Scientific Knowledge \\
\hline Scientific skills & $\begin{array}{l}\text { Proactive creativity } \\
\text { Research accuracy } \\
\text { Skill of accepting criticism }\end{array}$ \\
\hline Scientific abilities & Research abilities \\
\hline Intrinsic Motivation & Intrinsic Motivation \\
\hline Extrinsic Motivation & Extrinsic Motivation \\
\hline $\begin{array}{l}\text { Availability of financial resources } \\
\text { Availability of qualified human resources }\end{array}$ & Availability of financial and human resources \\
\hline $\begin{array}{l}\text { Availability of physical resources } \\
\text { Availability of digital resources }\end{array}$ & Availability of information resources \\
\hline
\end{tabular}

Table 6. Correspondence between theoretical and factorial analysis dimensions

Dependent variables:

Research performance is the dependent variable of the proposed model. From the researcher's name or ORCID code, we obtained the H-index of researchers in the Scopus database. The H-index (Hirsch, 2005) is generally used to measure research impact and quality, as it is not sensitive to the number of published documents, which happens with impact factor, thereby improving the assessment of a researcher's general impact (Egghe, 2008). Since the H-index presents some serious methodology restrictions, mainly related to distribution issues (Iglesias \& Pecharroman, 2007), we opted for to data envelopment analysis (DEA) to define an H-based efficiency frontier. DEA is a nonparametric linear-programming technique that compares multiple inputs and outputs of each sample researcher to the reference of optimal researchers (Amara, Rhaiem \& Halilem, 2020; Cook, Ramón, Ruiz, Sirvent \& Zhu, 2019). The efficiency measure is equivalent to the radial distance from the optimal frontier production (Papadimitriou \& Johnes, 2018; Sagarra, Molinero \& Agasisti, 2017). This frontier is obtained through the scores of each output category that is produced by the most efficient sample researcher (Kumar \& Thakur, 2019). In this study, we constructed this indicator based on the H-index, considering this measurement relative to a researcher's number of active years. This measure therefore makes it possible to compare researchers at different categories in their academic careers in comparison with other absolute indicators, such as the $\mathrm{H}$ index or productivity itself. This means that the DEA is more suitable as a dependent variable.

Control variables:

In line with similar studies, we decided to use length of academic career as a control variable to reduce the potential omitted bias variables in the empirical analysis (Leahey, Beckman \& Stanko, 2017; Bäker, 2015).

\section{Results}

With the purpose of contrasting the proposed hypotheses, four regression models have been developed using SPSS (version 21). Table 7 presents the correlation matrix of those variables used in the models together with their descriptive statistics. Table 8 presents the regression model results. Models 1 and 2 include the effect of the control variable and the researcher's human capital variable on individual scientific performance. The direct effects in Model 2 confirm that human capital has a positive and significant influence on individual scientific performance. More specifically, our results indicate that research abilities $(\mathrm{p}<0.01)$ and scientific knowledge $(\mathrm{p}<0.05)$ affect scientific performance. Our results do not indicate that research accuracy $(\mathrm{p}>0.10)$ and skill of accepting criticism $(\mathrm{p}>0.10)$ have a direct effect on individual scientific performance. However, the test results indicate certain negative and significant relationships between proactive creativity and individual scientific performance $(\mathrm{p}<$ 0.10). This result confirms Hypotheses 1a, $1 \mathrm{~b}$ and $1 \mathrm{~d}$ but rejects Hypothesis 1c. 
Models 3 and 4 incorporate the moderating effects as defined in the model: motivation (model 3) and opportunity (model 4). As indicated by the results (model 3), extrinsic motivation moderated the linkage between research abilities $(\mathrm{p}<0.01)$ and research knowledge $(\mathrm{p}<0.01)$ with individual scientific performance. In the case of intrinsic motivation, the moderation effects impact research abilities $(\mathrm{p}<0.05)$ is negative. While this moderation relation between intrinsic motivation and proactive creativity $(\mathrm{p}<0.01)$, research accuracy $(\mathrm{p}<0.01)$ and skill of accepting criticism $(\mathrm{p}<0.01)$ is positive. A significant change in $\mathrm{R}^{2}(0.411)$, after the interaction variable was added to the model, substantiates the moderating effect (refer to model 3). Consequently, hypotheses $2 \mathrm{a}$ and $2 \mathrm{~b}$ could be partially accepted. In accordance with $\mathrm{H} 3$, the researcher's opportunity moderated the linkage between academic human capital-researcher abilities and scientific performance. In this case, the moderating effect of availability of economic and human resources occurred for research abilities $(p<0.01)$, scientific knowledge $(p<0.01)$ and research accuracy $(\mathrm{p}<0.10)$. The moderating effect of availability of information resources arose for only two human capital dimensions: research abilities $(\mathrm{p}<0.01)$ and skill of accepting criticism $(\mathrm{p}<0.01)$. As indicated, a relative change in $\mathrm{R}^{2}(0.108)$, after the interaction variable was added to the model, explains the moderating effect (refer to model 4). These findings partially confirm Hypotheses 3a, 3b, 3c, and 3d.

\begin{tabular}{|c|c|c|c|c|c|c|c|c|c|c|c|c|c|c|}
\hline & Variable & $\mathbf{M}$ & DT & 1 & 2 & 3 & 4 & 5 & 6 & 7 & 8 & 9 & 10 & 11 \\
\hline 1 & $\begin{array}{l}\text { Research } \\
\text { abilities }\end{array}$ & 0 & 1 & 1 & & & & & & & & & & \\
\hline 2 & $\begin{array}{l}\text { Scientific } \\
\text { knowledge }\end{array}$ & 0 & 1 & .000 & 1 & & & & & & & & & \\
\hline 3 & $\begin{array}{l}\text { Proactive } \\
\text { creativity }\end{array}$ & 0 & 1 & .000 & .000 & 1 & & & & & & & & \\
\hline 4 & $\begin{array}{l}\text { Research } \\
\text { accuracy }\end{array}$ & 0 & 1 & .000 & .000 & .000 & 1 & & & & & & & \\
\hline 5 & $\begin{array}{l}\text { Skill of } \\
\text { accepting } \\
\text { criticism }\end{array}$ & 0 & 1 & .000 & .000 & .000 & .000 & 1 & & & & & & \\
\hline 6 & $\begin{array}{l}\text { Extrinsic } \\
\text { motivation }\end{array}$ & 0 & 1 & -.005 & -.019 & -.054 & .064 & -.006 & 1 & & & & & \\
\hline 7 & $\begin{array}{l}\text { Intrinsic } \\
\text { motivation }\end{array}$ & 0 & 1 & $.314 * *$ & $.225 * *$ & $.340^{* *}$ & -.039 & -.066 & .000 & 1 & & & & \\
\hline 8 & $\begin{array}{l}\text { Availability } \\
\text { of human } \\
\text { and } \\
\text { financial } \\
\text { resources }\end{array}$ & 0 & 1 & .044 & .040 & .000 & -.075 & .011 & .037 & .090 & 1 & & & \\
\hline 9 & $\begin{array}{l}\text { Availability } \\
\text { of } \\
\text { information } \\
\text { resources }\end{array}$ & 0 & 1 & -.025 & .036 & $.120^{*}$ & .045 & . 086 & .072 & .027 & .000 & 1 & & \\
\hline 10 & DEA & .420 & .139 & $.299 * *$ & $.101 *$ & -.069 & .001 & -.018 & -.077 & .069 & $.223 * *$ & $.121 *$ & 1 & \\
\hline 11 & $\begin{array}{l}\text { Length of } \\
\text { academic } \\
\text { career }\end{array}$ & 4.459 & .900 & $.098^{*}$ & $.133^{* *}$ & .032 & .082 & .013 & $-.131 * *$ & . 017 & -.027 & . 071 & $.125^{*}$ & 1 \\
\hline
\end{tabular}

Table 7. Descriptive statistics and correlations 


\begin{tabular}{|c|c|c|c|c|}
\hline Variables & Model 1 & Model 2 & Model 3 & Model 4 \\
\hline Constant & $\begin{array}{r}.337 * * \\
(.034)\end{array}$ & $\begin{array}{r}.358^{* *} \\
(.034)\end{array}$ & $\begin{array}{r}.387 * * \\
(.026)\end{array}$ & $\begin{array}{r}.353^{* *} \\
(.029)\end{array}$ \\
\hline Length of academic career & $\begin{array}{l}.015^{*} \\
(.007)\end{array}$ & $\begin{array}{r}.011 \\
(.007)\end{array}$ & $\begin{array}{r}.004 \\
(.006)\end{array}$ & $\begin{array}{l}.011+ \\
(.007)\end{array}$ \\
\hline Research abilities & & $\begin{array}{l}.052^{* *} \\
(.005)\end{array}$ & $\begin{array}{r}.059 * * \\
(.005)\end{array}$ & $\begin{array}{r}.052^{* *} \\
(.005)\end{array}$ \\
\hline Scientific knowledge & & $\begin{array}{l}0.19^{*} \\
(.008)\end{array}$ & $\begin{array}{l}.014^{*} \\
(007)\end{array}$ & $\begin{array}{l}.018^{*} \\
(.007) \\
\end{array}$ \\
\hline Proactive creativity & & $\begin{array}{r}-.013+ \\
(.007) \\
\end{array}$ & $\begin{array}{r}.002 \\
(.005)\end{array}$ & $\begin{array}{r}-.016^{*} \\
(.007)\end{array}$ \\
\hline Research accuracy & & $\begin{array}{r}.001 \\
(.008) \\
\end{array}$ & $\begin{array}{r}.001 \\
(.005) \\
\end{array}$ & $\begin{array}{r}.000 \\
(.007) \\
\end{array}$ \\
\hline Skill of accepting criticism & & $\begin{array}{r}-.003 \\
(.009)\end{array}$ & $\begin{array}{r}.001 \\
(.004)\end{array}$ & $\begin{array}{l}-.007 \\
(.009) \\
\end{array}$ \\
\hline Extrinsic motivation x Research abilities & & & $\begin{array}{l}.034 * * \\
(.005)\end{array}$ & \\
\hline Extrinsic motivation x Scientific knowledge & & & $\begin{array}{r}.048^{* *} \\
(.009)\end{array}$ & \\
\hline Extrinsic motivation x Proactive creativity & & & $\begin{array}{r}.001 \\
(.005)\end{array}$ & \\
\hline Extrinsic motivation x Research accuracy & & & $\begin{array}{r}-.001 \\
(.005)\end{array}$ & \\
\hline Extrinsic motivation x Skill of accepting criticism & & & $\begin{array}{r}.005 \\
(006)\end{array}$ & \\
\hline Intrinsic motivation x Research abilities & & & $\begin{array}{l}-.009^{*} \\
(.004)\end{array}$ & \\
\hline Intrinsic motivation x Scientific knowledge & & & $\begin{array}{l}-.003 \\
(.004)\end{array}$ & \\
\hline Intrinsic motivation $x$ Proactive creativity & & & $\begin{array}{l}.045^{* *} \\
(.004)\end{array}$ & \\
\hline Intrinsic motivation x Research accuracy & & & $\begin{array}{l}.037 * * \\
(.004)\end{array}$ & \\
\hline Intrinsic motivation $x$ Skill of accepting criticism & & & $\begin{array}{l}.043^{* *} \\
(.004)\end{array}$ & \\
\hline Availability of economic and human resources $x$ Research abilities & & & & $\begin{array}{r}.048^{* *} \\
(.007)\end{array}$ \\
\hline Availability of economic and human resources x Scientific knowledge & & & & $\begin{array}{l}.036^{* *} \\
(.009)\end{array}$ \\
\hline Availability of economic and human resources x Proactive creativity & & & & $\begin{array}{r}.000 \\
.008)\end{array}$ \\
\hline Availability of economic and human resources x Research accuracy & & & & $\begin{array}{l}.014+ \\
(.008)\end{array}$ \\
\hline $\begin{array}{l}\text { Availability of economic and human resources } \mathrm{x} \text { Skill of accepting } \\
\text { criticism }\end{array}$ & & & & $\begin{array}{r}.011 \\
(.007)\end{array}$ \\
\hline Availability of information resources $x$ Research abilities & & & & $\begin{array}{r}.027 * * \\
.008)\end{array}$ \\
\hline Availability of information resources $x$ Scientific knowledge & & & & $\begin{array}{r}.003 \\
(.007)\end{array}$ \\
\hline Availability of information resources $x$ Proactive creativity & & & & $\begin{array}{l}-.008 \\
(.006)\end{array}$ \\
\hline Availability of information resources $x$ Research accuracy & & & & $\begin{array}{r}.010 \\
(.006) \\
\end{array}$ \\
\hline Availability of information resources $x$ Skill of accepting criticism & & & & $\begin{array}{r}.022^{* *} \\
(.007)\end{array}$ \\
\hline Model F & $4.222 *$ & $27.261 * *$ & $48.202^{* *}$ & $11.356^{* *}$ \\
\hline Model $\mathrm{R}^{2}$ & .015 & .183 & .594 & .291 \\
\hline Increase $\mathrm{R}^{2}$ & - & .168 & .411 & .108 \\
\hline \multicolumn{5}{|c|}{$\begin{array}{l}\text { Notes: } n=471 .: \text { Dependent variable: DEA } \\
\text { The table presents the non-standardized beta coefficients, the standardized errors clustered are found between brackets, and the change in } \mathrm{R}^{2} \\
\text { indicates the comparison with the previous model. } \\
+p<.10 ; * p<.05 ; * * p<.01\end{array}$} \\
\hline
\end{tabular}

Table 8. Linear regression model results 


\section{Discussion}

The literature considers that human capital has a positive and significant influence on individual performance. Studies such McNie et al. (2016) argue that both "hard skills" and "soft skills" are necessary for research performance. Hard skills are those capabilities that allow an individual to formulate hypotheses, develop research protocols, undertake research, and publish articles. On the other hand, soft skills are the capabilities of academic researchers that focus on behaviour and relationships. Therefore, we would consider research abilities and scientific knowledge as "hard skills" and regard proactive creativity, research accuracy and skill of accepting criticism as "soft skills". In fact, our data suggest that scientific knowledge and research abilities are the essence of academic human capital, as described by studies such Bozeman et al. (2001) and Durette et al. (2016). In addition, our results do not show that research accuracy and skill of accepting criticism had a direct effect on individual scientific performance. However, the test results indicate certain negative and significant relationships between proactive creativity and individual scientific performance. These findings are partially unexpected because theoretically, all human capital factors should contribute significantly and positively to individual scientific performance. One possible explanation is that researchers have very innovative and creative proposals that hinder publication in scientific journals, hence undermining performance. This relationship needs to be investigated further to confirm its existence as well as significance.

Similarly, we have shown that the explanatory model improves when it includes the researcher's motivation and opportunity as moderating variables. In view of the results, we can confirm that researcher motivation contributes as a moderating variable rather than the researcher opportunity dimensions $\left(R^{2}=0.411\right.$ vs $R^{2}=$ 0.108). According to our model in relation to the researcher's motivation, individual scientific performance is a product of an interaction between the researcher's intrinsic and extrinsic motivation and his or her abilities (academic human capital), as indicated in studies such as Janger and Nowotny (2016). Our results seem to indicate that extrinsic motivation encourages "hard skills" (research abilities and scientific knowledge), while intrinsic motivation stimulates "soft skills" (proactive creativity, research accuracy and skill of accepting criticism). Specifically, improvement in contractual conditions and financial rewards relevant to extrinsic motivation increases the effect of research ability and scientific knowledge on individual scientific performance. On the other hand, intrinsic motivation strengthens the effect of research skills (proactive creativity, research accuracy and skill of accepting criticism) on individual scientific performance. However, the moderation effect of intrinsic motivation between research abilities on individual scientific performance is negative. One reason could be the sample chosen, which included only individuals with permanent positions. The results indicate that academic researchers have adequate research abilities, and they do not particularly benefit from being intrinsically motivated to perform research. Therefore, further study is necessary to confirm these findings. In short, we can confirm that academic researchers have the same intrinsic and extrinsic motivations as other employees in different organizations.

In relation to researcher opportunities, our results support the proposals of other studies, such as Van der Weijden, de Gilderb, Groenewegenb and Klasenc (2008) and Sutherland (2017). As expected, universities providing economic and human resources reinforce the relationships between their researchers' abilities (academic human capital) and scientific performance. More specifically, the availability of economic and buman resources enhances the effect of "hard skills" (research abilities and scientific knowledge) and one of the dimensions of "soft skills" (research accuracy). The same effect is not supported for the availability of information except for one dimension of "hard skill" (research abilities) and the last dimension of "soft skills" (skill of accepting criticism). One reason for this result could be, as previously stated, the sample used. Economic and human resources allow academic researchers to continue acquiring knowledge, abilities and greater discipline to achieve higher scientific performance. In the case of information resources, the results seem to indicate that they are not very necessary to publish for academic researchers who have obtained a tenured position. Information resources enable researchers to accept criticism as they observe the research of their peers.

\section{Conclusions}

The aim of this study was to identify the factors that determine individual academics' scientific performance. From a theoretical perspective, we looked to examine the applicability of the AMO model in an academic 
context. We applied this model to explore how motivation and opportunity affect researchers' abilities (their academic human capital). Although several studies indicate that AMO theory is an appropriate framework for explaining individual performance (Bos-Nehles et al., 2013), few have considered the research academic context. Nevertheless, the dimensions proposed by AMO theory have helped identify the specific factors that have a significant impact on individual scientific performance. We therefore offer a novel model, based on the AMO framework, that explains whether research abilities improve in the presence of different types of research motivations and opportunities. In a mixed methodology study, our proposed hypotheses were widely supported. Theoretically, the reported research contributed toward the existing breadth of knowledge on the factors that influence academic researchers in terms of their abilities, motivations, and opportunities in their field. We believe that our focus on motivation and opportunity for research can be used to explain performance improvements in a given individual researcher's abilities.

More specifically, these research findings contribute to the literature in several different ways. First, the proposed model, based on AMO theory, has helped thoroughly explain the relationship between the prescribed dimensions and individual scientific performance. AMO theory offers a better understanding of this phenomenon and of the interrelationships between researchers' abilities (academic human capital), motivation, and opportunities. It is worth noting that, despite the evident contextual differences, researchers seem to respond to concerns in ways that are similar to workers in different organizational contexts (Szulc, Davies, Tomczak \& McGregor, 2021; Szulc \& Smith, 2021). Academic researchers, like other workers, develop a series of abilities and motivations that allow them to achieve certain returns in their jobs. Likewise, the opportunities offered by their organizations and environments allow them to make improvements, as shown in this study. Additionally, our study contributes to identifying specific variables within the academic context: five that are academic human capital-based (research abilities, scientific knowledge, proactive creativity, research accuracy, and skill of accepting criticism), two that are research motivation-based (extrinsic and intrinsic motivation) and that are two research opportunity-based (availability of economic and buman resources and availability of information resources). These elements are essential for the successful academic activity of university researchers. The different research units (universities, research groups, and researchers) can utilize these attributes in order to encourage research activity. In complex jobs like conducting research, a comprehensive list of AMO attributes could be especially useful in analysing one's position in order to clarify what is needed to successfully perform. Secondly, the tests indicated that researchers' abilities (academic human capital) have a positive influence on individual scientific performance. The positive influence of human capital on research activity implies that researchers must acquire, maintain, and develop a set of specific competencies to appropriately carry out research activity; these results, as expected, are consistent with the academic human capital literature (Bozeman et al., 2001). Surprisingly, our results reflect a certain negative relationship between proactive creativity and performance, perhaps because the research process and lines of research groups somewhat limit the "gaps" in the different research topics or innovative proposals that are generally not sought after in scientific journals. According to our results, academic researchers have both an extrinsic motivation that encourages hard skills (research abilities and scientific knowledge), and an intrinsic motivation that stimulates soft skills (proactive creativity, research accuracy, and skill of accepting criticism). This study therefore supports previous conclusions in the literature regarding the connection between intrinsic and extrinsic researcher motivation in the academic context (Janger \& Nowotny, 2016; Wollersheim et al., 2015). In fact, the theoretical discussion describes a two-way relationship between these two motivation dimensions on scientific performance (Peng \& Gao, 2019). Additionally, researchers' opportunities are particularly relevant in the academic context. Although opportunities for researchers to engage in scientific activity have been explored previously, this study highlights the necessity of going beyond description by employing inferential statistics to examine the relationships between research abilities and scientific performance; our participants exhibited a greater availability of economic and human resources than of information resources. According to our results, economic and human resources must be available to support researchers' "hard skills" (research abilities and scientific knowledge) and certain one dimension of "soft skills" (research accuracy). However, our data indicated the availability of information resources in terms of only one dimension of "hard skills" (research abilities) and the last dimension of "soft skills" (skill of accepting criticism). Therefore, we can conclude that researchers' motivation and opportunities stimulate their ability to achieve greater scientific performance. 
From a practical perspective, this study has a number of implications that may be relevant for university managers and PIs who strive to advance the quality and effectiveness of academic human capital (researchers' abilities), foster researchers' motivation, and offer the opportunities required for conducting research. The conceptual model presented here can help universities develop a comprehensive approach to abilities, motivation, and opportunity enhancement practices tailored to the specific needs of researchers in the given workplace. More specifically, adequate policies for hiring new academic researchers, training, researcher evaluations, and academic rewards (Thunnissen \& Van Arensbergen, 2015; Ayaita, Pull, Backes-Gellner, 2019) could impact the development of researchers' abilities and motivation. Thus, university managers must promote adequate human resource management policies that improve the ability and motivation of academic researchers; these are both directly and indirectly related to research performance, suggesting that universities retain and generate high levels of performance of researchers focusing on the potential relationships that drive them. Also, universities who provide researchers with the necessary resources (financial, human, and information), are likely to enable them to improve their research performance. Since research collaborations are commonly positively associated with development and performance outcomes (Lee and Bozeman, 2005), cooperation between new researchers and support staff can both facilitate the creation of new research abilities and provide a more holistic view of job satisfaction, for example. A second practical implication of the AMO framework can be seen in its usefulness as an external reporting tool. The AMO framework could be utilized at the university level to better allocate resources and foster academic motivation. University leaders could therefore use this study to develop ability-motivation-and opportunity enhancing strategies and methods to help researchers improve individual scientific performance; Andreeva and Sergeeva (2016) and Beltran-Martín and Bou-Llusar (2018) showed examples of this in the organizational context.

\section{Limitations and directions for future research}

Our study has a number of limitations that offer potential directions for future research. First, the analysis of the complex relationships between the examined factors requires a longitudinal investigation in order to correctly identify the dynamics existing between the different elements of the model. Moreover, the findings suggest that the results may be affected by specific characteristics within a given field of study. Further analyses should be performed to study which characteristics of a field are the most relevant, as they may eventually influence the results. Secondly, we need to acknowledge the sample's national character; this study should be replicated at an international level considering the differences in each AMO variable that might be affected by contextual variables. Finally, another limitation of the study could be mitigated by separating the results according to university regional context, field of study, or academic rank; these results could illuminate differences between these variables, primarily in terms of the availability of resources.

\section{Declaration of Conflicting Interests}

The authors declared no potential conflicts of interest with respect to the research, authorship, and/or publication of this article.

\section{Funding}

Authors are ordered alphabetically and have contributed equally to this paper. This study was supported by:

1.- The Spanish Ministry of Economy and Competitively under Grant ECO2014-56580-R;

2.- The Andalusian Government (Spain) under Grant P12-SEJ-1810;

3.- The Andalusian Government (Spain) under Grant P12-SEJ-1618; and

4.- Research Projects University of Cadiz under Grant PR2016-018.

\section{References}

Auranen, O., \& Nieminen, M. (2010). University research funding and publication performance-An international comparison. Research Policy, 39, 822-834. https://doi.org/10.1016/j.respol.2010.03.003 
Agasisti, T., Catalano, G., Landoni, P., \& Verganti, R. (2012). Evaluating the performance of academic departments: An analysis of research-related output efficiency. Research Evaluation, 21, 2-14. https://doi.org/10.1093/reseval/rvr001

Agasisti, T., Dal Bianco, A, Landoni, P., Sala, A., \& Salerno, M. (2011). Evaluating the Efficiency of Research in Academic Departments: an Empirical Analysis in an Italian Region. Higher Education Quarterly, 65(3), 267-289. https://doi.org/10.1111/j.1468-2273.2011.00489.x

Amara, N., Rhaiem, M., \& Halilem, N. (2020). Assessing the research efficiency of Canadian scholars in the management field: Evidence from the DEA and fsQCA. Journal of Business Research, 115, 296-306. https://doi.org/10.1016/j.jbusres.2019.10.059

Andreeva, T., \& Sergeeva, A. (2016). The more the better ... or is it? The contradictory effects of HR practices on knowledge-sharing motivation and behaviour. Human Resource Management Journal, 26(2), 151-171. https://doi.org/10.1111/1748-8583.12100

Appelbaum, E., Bailey, T.T., Berg, P., \& Kallenberg, A. (2000). Manufacturing advantage: Why high-performance work systems pay off. Ithaca, NY: Cornell University Press.

Ayaita, A., Pull, K., Backes-Gellner, U. (2019). You get what you 'pay'for: Academic attention, career incentives and changes in publication portfolios of business and economics researchers. Journal of Business Economics, 89(3), 273-290. https://doi.org/10.1007/s11573-017-0880-6

Bäker, A. (2015). Non-tenured post-doctoral researchers'job mobility and research output: An analysis of the role of research discipline, department size, and coauthors. Research Policy, 44, 634-650.

https://doi.org/10.1016/j.respol.2014.12.012

Barham, B.L., Foltz, J.D., \& Prager, D. (2014). Making time for science. Research Policy, 43, 21-31. https://doi.org/10.1016/j.respol.2013.08.007

Bazeley, P. (2010). Conceptualising research performance. Studies in Higher Education, 35(8), 889-903. https://doi.org/10.1080/03075070903348404

Bell, E., \& Bryman, A. (2007). The ethics of management research: An exploratory content analysis. British Journal of Management, 18, 63-77. https://doi.org/10.1111/j.1467-8551.2006.00487.x

Beltrán-Martín, I., \& Bou-Llusar, J.C. (2018). Examining the intermediate role of employee abilities, motivation and opportunities to participate in the relationship between HR bundles and employee performance. Business Research Quaterly, 21, 99-110. https://doi.org/10.1016/j.brq.2018.02.001

Benet-Zepf, A., Marin-Garcia, J., \& Küster, I. (2018). Clustering the mediators between the sales control systems and the sales performance using the AMO model: A narrative systematic literature review. Intangible Capital, 14(3), 387-408. https://doi.org/10.3926/ic.1222

Bentler, P.M. (1995). EQS Structural Equations Program Manual. Encino, CA: Multivariate Software Inc.

Bentley, P.J., \& Kyvik, S. (2013). Individual Differences in Faculty Research Time Allocations Across 13 Countries. Research in Higher Education, 54(3), 329-348. https://doi.org/10.1007/s11162-012-9273-4

Bland, C.J., Center, B.A., Finstad, D.A., Risbey, K.R., \& Staples, J.G. (2005). A theoretical, practical, predictive model of faculty and department research productivity. Academic Medicine: Journal of the Association of American Medical Colleges, 80(3), 225-237. https://doi.org/10.1097/00001888-200503000-00006

Blumberg, M., \& Pringle, C. (1982). The missing opportunity in organizational research: Some implications for a theory of work performance. Academy of Management Review, 7(4), 560-569.

https://doi.org/10.5465/amr.1982.4285240

Bos-Nehles, A.C., Van Riemsdijk, M.J., \& Kees-Looise, J. (2013). Employee perceptions of line management performance: Applying the AMO theory to explain the effectiveness of line managers' HRM implementation, Human Resource Management, 52(6), 861-877. https://doi.org/10.1002/hrm.21578 
Bouwmans, M., Runhaar, P., Wesselink, R., \& Mulder, M. (2019). Stimulating teachers' team performance through team-oriented HR practices: the roles of affective team commitment and information processing. The International Journal of Human Resource Management, 30(5), 856-878.

https://doi.org/10.1080/09585192.2017.1322626

Boxall, P., \& Purcell, J. (2003). Strategy and Human Resource Management. Basingstoke: Palgrave Macmillan.

Bozeman, B., Dietz, J., \& Gaughan, M. (2001). Scientific and Technical Human Capital: An Alternative Model for Research Evaluation. International Journal of Technology Management, 22(8), 716-740. https://doi.org/10.1504/IJTM.2001.002988

Buchmueller, T.C., Dominitz, J., \& Hansen, W.L. (1999). Graduate training and the early career productivity of Ph. D. economists. Economics of Education Review, 18(1), 65-77. https://doi.org/10.1016/S0272-7757(98)00019-3

Carayol, N, \& Matt, M. (2004). Does research organization influence academic production? Laboratory level evidence from a large European university. Research Policy, 33(8), 1081-1102.

https://doi.org/10.1016/j.respol.2004.03.004

Cattell, R.B. (1966). The Scree Test for the Number of Factors. Multivariate Behavioral Research, 1, 245-276. https://doi.org/10.1207/s15327906mbr0102_10

Chen, Y., Gupta, A., \& Hoshower, L. (2006). Factors That Motivate Business Faculty to Conduct Research: An Expectancy Theory Analysis. Journal of Education for Business, 81(4), 179-189. https://doi.org/10.3200/JOEB.81.4.179-189

Coff, R., \& Kryscynski, D. (2011). Invited Editorial: Drilling for Micro-Foundations of Human Capital-Based Competitive Advantages. Journal of Management, 37(5), 1429-1443. https://doi.org/10.1177/0149206310397772

Conway, J.M., \& Lance, C.E. (2010). What reviewers should expect from authors regarding common method bias in organizational research. Journal of Business and Psychology, 25, 325-334. https://doi.org/10.1007/s10869-0109181-6

Cook, W.D., Ramón, N., Ruiz, J.L., Sirvent, I., \& Zhu, J. (2019). DEA-based benchmarking for performance evaluation in pay-for-performance incentive plans. Omega, 84, 45-54.

https://doi.org/10.1016/j.omega.2018.04.004

Curtin, N., Malley, J., \& Stewart, A.J. (2016). Mentoring the Next Generation of Faculty: Supporting Academic Career Aspirations Among Doctoral Students. Research in Higher Education, 57, 714-738. https://doi.org/10.1007/s11162-015-9403-x

Deemer, E.D., Martens, M.P., \& Buboltz, W.C. (2010). Toward a Tripartite Model of Research Motivation: Development and Initial Validation of the Research Motivation Scale. Journal of Career Assessment, 18(3), 292-309. https://doi.org/10.1177/1069072710364794

Delamont, S., Atkinson, P., \& Parry, O. (1997). Critical mass and doctoral research: reflections on the Harris report. Studies in Higher Education, 22(3), 319-331. https://doi.org/10.1080/03075079712331380926

Diem, A., \& Wolter, S.C. (2013). The Use of Bibliometrics to Measure Research Performance in Education Sciences. Research in Higher education, 54, 86-114. https://doi.org/10.1007/s11162-012-9264-5

Dundar, H., \& Lewis, D.R. (1998). Determinants of research productivity in higher education. Research in higher education, 39(6), 607-631. https://doi.org/10.1023/A:1018705823763

Durette, B., Fournier, M., \& Lafon, M. (2016). The core competencies of PhDs. Studies in Higher Education, 41(8), 1355-1370. https://doi.org/10.1080/03075079.2014.968540

Egghe, L. (2008). Mathematical theory of the h- and g-index in case of fractional counting of authorship. Journal of the American Society for Information Science and Technology, 59(10), 1608-1616. https://doi.org/10.1002/asi.20845

Fox, M.F. (1983). Publication Productivity among Scientists: A Critical Review. Social Studies of Science, 13(2), 285-305. https://doi.org/10.1177/030631283013002005 
Gonzalez-Brambila, C., \& Veloso, F.M. (2007). The determinants of research output and impact: A study of Mexican researchers. Research policy, 36, 1035-1051. https://doi.org/10.1016/j.respol.2007.03.005

Hardre, P.L., \& Kollmann, S.L. (2012). Motivational Implications of Faculty Performance Standards. Educational Management Administration \& Leadership, 40(6), 724-751. https://doi.org/10.1177/1741143212456913

Harris, C.M., McMahan, G.C., \& Wright, P.M. (2012). Talent and time together: The impact of human capital and overlapping tenure on unit performance. Personnel Review, 41(4), 408-427. https://doi.org/10.1108/00483481211229357

Hedjazi, Y., \& Behravan, J. (2011). Study of factors influencing research productivity of agriculture faculty members in Iran. Higher education, 62(5), 635-647. https://doi.org/10.1007/s10734-011-9410-6

Hicks, D. (2012). Performance-based university research funding systems. Research Policy, 41(2), 251-261. https://doi.org/10.1016/j.respol.2011.09.007

Hirsch, J.E. (2005). An index to quantify an individual's scientific research output. Proceedings of the National Academy of Sciences of the United States of America, 102(46), 16569-16572. https://doi.org/10.1073/pnas.0507655102

Horta, H., \& Santos, J.M. (2016). The impact of publishing during PhD studies on career research publication, visibility, and collaborations. Research in Higher Education, 57(1), 28-50. https://doi.org/10.1007/s11162-015-93800

Iglesias, J.E., \& Pecharroman, C. (2007). Scaling the h-index for different scientific ISI fields. Scientometrics, 73(3),303-320. https://doi.org/10.1007/s11192-007-1805-x

Janger, J, \& Nowotny, K. (2016). Job choice in academia. Research Policy, 45(8), 1672-1683. https://doi.org/10.1016/j.respol.2016.05.001

Jiang, K, Lepak, D.P., Hu, J., \& Baer, J.C. (2012). How Does Human Resource Management Influence Organizational Outcomes? A Meta-analytic Investigation of Mediating Mechanisms. Academy of Management Journal, 55(6), 1264-1294. https://doi.org/10.5465/amj.2011.0088

Johns, G. (2017). Reflections on the 2016 decade award: incorporating context in organisational research. Academy of Management Review, 42, 577-595. https://doi.org/10.5465/amr.2017.0044

Kaiser, H.F. (1974). An Index of Factorial Simplicity. Psychometrika, 39, 31-36. https://doi.org/10.1007/BF02291575

Käpylä, J, Jääskeläinen, A, \& Lönnqvist, A. (2010). Identifying future challenges for productivity research: Evidence from Finland. International Journal of Productivity and Performance Management, 59(7), 607-623. https://doi.org/10.1108/17410401011075620

Karasek, R.A. (1979). Job demands, job decision latitude and mental strain. Implications for job redesign. Administrative Science Quarterly, 24, 285-308. https://doi.org/10.2307/2392498

Kim, K.Y, Pathak, S, \& Werner, S. (2015). When do international human capital enhancing practices benefit the bottom line? An ability, motivation, and opportunity perspective. Journal of International Business Studies, 46(7), 784-805. https://doi.org/10.1057/jibs.2015.10

Knies, E, \& Leisink P. (2014). Linking people management and extra-rolebehaviour: Results of a longitudinal study. Human Resource Management Journal, 24(1), 57-76. https://doi.org/10.1111/1748-8583.12023

Kumar, A, \& Thakur, R.R. (2019). Objectivity in performance ranking of higher education institutions using dynamic data envelopment analysis. In press. https://doi.org/10.1108/IJPPM-03-2018-0089

Kwiek, M. (2016). The European research elite: A cross-national study of highly productive academics in 11 countries. Higher Education, 71(3), 379-397. https://doi.org/10.1007/s10734-015-9910-x

Landeta, J. (1999). El método Delphi, una técnica de previsión del futuro. Barcelona: Ariel S.A. 
Lariviere, V, Macaluso, B, Archambault, E, \& Gingras, Y. (2010). Which scientific elites? On the concentration of research funds, publications and citations. Research Evaluation, 19, 45-53.

https://doi.org/10.3152/095820210X492495

Leahey, E, Beckman, C.M, \& Stanko, T.L. (2017). Prominent but less productive: the impact of interdisciplinarity on scientifist's research. Administrative Science Quaterly, 62(1),105-139. https://doi.org/10.1177/0001839216665364

Lee, S., \& Bozeman, B. (2005). The impact of research collaboration on scientific productivity. Social studies of science, 35(5), 673-702. https://doi.org/10.1177/0306312705052359

Lee, H.F, Miozzo M, \& Laredo, P. (2010). Career patterns and competences of PhDs in science and engineering in the knowledge economy: The case of graduates from a UK research-based university. Research Policy, 39(7), 869-881. https://doi.org/10.1016/j.respol.2010.05.001

Lepak, D.P, Liao, H, Chung, Y, \& Harden, E. (2006). A conceptual review of human resource management systems in strategic human resource management research. Research in Personnel and Human Resource Management, 25(1), 217-271. https://doi.org/10.1016/S0742-7301(06)25006-0

Levecque, K, Ansell, F, De Beuckelaer, A, Van der Heyden, J, \& Gisle, L. (2017) Work organization and mental health problems in PhD students. Research Policy, 46, 868-879. https://doi.org/10.1016/j.respol.2017.02.008

Lindell, M.K, \& Whitney, D.J. (2001). Accounting for common method variance in cross-sectional research designs. Journal of applied psychology, 86(1), 114. https://doi.org/10.1037/0021-9010.86.1.114

Lissoni, F, Mairesse, J, Montobbio, F, \& Pezzoni, M. (2011). Scientific productivity and academic promotion: a study on French and Italian physicists. Industrial and Corporate Change, 20(1), 253-294.

https://doi.org/10.1093/icc/dtq073

Lovitts, B.E. (2005). Being a good course-taker is not enough: A theoretical perspective on the transition to independent research. Studies in Higher Education, 30(2), 137-154. https://doi.org/10.1080/03075070500043093

MacDuffie, J.P. (1995). Human resource bundles and manufacturing performance: Organizational logic and flexible production systems in the world auto industry. Industrial and Labor Relations Review, 48(2), 197-221. https://doi.org/10.1177/001979399504800201

Marie, J. (2008). Postgraduate science research skills: the role of creativity, tacit knowledge, thought styles and language. London Review of Education, 6(2), 149-158. https://doi.org/10.1080/14748460802185136

Marin-Garcia, J.A, \& Martinez-Tomas, J. (2016). Deconstructing AMO framework: A systematic review Intangible Capital, 12(4), 1040-1087. https://doi.org/10.3926/ic.838

McNie, E.C, Parris, A, \& Sarewitz, D. (2016). Improving the public value of science: A typology to inform discussion, design and implementation of research. Research Policy, 45(4), 884-895.

https://doi.org/10.1016/j.respol.2016.01.004

Mitchell, T.R. (1982). Motivation: New directions for theory, research and practice. Academy of Management Review, 7(1), 80-88. https://doi.org/10.5465/amr.1982.4285467

Mudrak, J., Zabrodska, K., Kveton, P., Jelinek, M., Blatny, M., Solcova, I. et al. (2018). Occupational well-being among university faculty: A job demands-resources model. Research in Higher Education, 59(3), 325-348. https://doi.org/10.1007/s11162-017-9467-x

Nguyen, T.L.H. (2016). Building human resources Management capacity for university research: The case at four leading Vietnamese universities. Higher education, 71, 231-251. https://doi.org/10.1007/s10734-015-9898-2

Nonaka I., \& Takeuchi, H. (1995). The Knowledge-creating Company: How Japanese Companies Create the Dynamics of Innovation. Oxford University Press. https://doi.org/10.1016/0024-6301(96)81509-3

Okoli, C., \& Pawlowski, S.D. (2004). The Delphi method as a research tool: an example, design considerations and applications. Information \& Management, 42(1), 15-29. https://doi.org/10.1016/j.im.2003.11.002 
Papadimitriou, M., \& Johnes, J. (2018). Does merging improve efficiency? A study of English universities. In Press. https://doi.org/10.1080/03075079.2018.1450851

Ployhart, R.E., \& Moliterno, T.P. (2011). Emergence of the human capital resource: A mulitlevel model. Academy of Management Review, 36(1), 127-150. https://doi.org/10.5465/amr.2009.0318

Peng, J.E., \& Gao X. (2019). Understanding TEFL Academics' Research Motivation and Its Relations with Research Productivity. SAGE Open, 9(3), 2158244019866295. https://doi.org/10.1177/2158244019866295

Podsakoff, P.M., MacKenzie, S.B., Lee, J.Y., \& Podsakoff, N.P. (2003). Common method biases in behavioral research: a critical review of the literature and recommended remedies. Journal of Applied Psychology, 88(5), 879-903. https://doi.org/10.1037/0021-9010.88.5.879

Prpić, K. (1996). Characteristics and determinants of eminent scientists' productivity. Scientometrics, 36(2), 185-206. https://doi.org/10.1007/BF02017313

Rorstad, K., \& Aksnes, D.W. (2015). Publication rate expressed by age, gender and academic position - A largescale analysis of Norwegian academic staff. Journal of Informetrics, 9, 317-333.

https://doi.org/10.1016/j.joi.2015.02.003

Rowley, J. (2000). Is higher education ready for knowledge management?. International Journal of Educational Management, 14(7), 325-333. https://doi.org/10.1108/09513540010378978

Runhaar, P. (2017). How can schools and teachers benefit from human resources management? Conceptualising HRM from content and process perspectives. Educational Management Administration \& Leadership, 45(4), 639-656. https://doi.org/10.1177/1741143215623786

Sagarra, M., Molinero, C.M., \& Agasisti, T. (2017). Exploring the efficiency of Mexican universities: Integrating Data Envelopment Analysis and Multidimensional Scaling. Omega, 67,123-133.

https://doi.org/10.1016/j.omega.2016.04.006

Shmatko, N., \& Volkora, G. (2017). Service or Devotion?. Motivation Patterns of Russian Researchers. Foresight and STI Governance, 11(2),54-66. https://doi.org/10.17323/2500-2597.2017.1.54.66

Schuelke-Leech, B.A. (2013). Resources and research: An empirical study of the influence of departmental research resources on individual STEM researchers involvement with industry. Research Policy, 42(9), 1667-1678. https://doi.org/10.1016/j.respol.2013.06.010

Siemsen, E., Roth, A.V., \& Balasubramanian, S. (2008). How motivation, opportunity, and ability drive knowledge sharing: The constraining-factor model. Journal of Operations Management, 26(3), 426-445.

https://doi.org/10.1016/i.jom.2007.09.001

$\mathrm{Su}, \mathrm{X}$. (2011). Postdoctoral training, departmental prestige and scientists' research productivity. The Journal of Technology Transfer, 36(3), 275-291. https://doi.org/10.1007/s10961-009-9133-3

Sutherland, K.A. (2017). Constructions of success in academia: an early career perspective. Studies in Higher Education, 42(4),743-759

Szulc, J.M., Davies, J., Tomczak, M.T., \& McGregor, F.L. (2021). AMO perspectives on the well-being of neurodivergent human capital. Employee Relations, 43(4), 858-872. https://doi.org/10.1108/ER-09-2020-0446

Szulc, J.M., \& Smith, R. (2021). Abilities, Motivations, and Opportunities of Furloughed Employees in the Context of Covid-19: Preliminary Evidence From the UK. Frontiers in Psychology, 12, 635144. https://doi.org/10.3389/ fpsyg.2021.635144

Thunnissen, M., \& Van Arensbergen, P. (2015). A multi-dimensional approach to talent: An empirical analysis of the definition of talent in Dutch academia. Personnel Review, 44(2), 182-199. https://doi.org/10.1108/PR-10-20130190 
Tiam, J., Nakamori, Y., \& Wierzbicki, A.P. (2009). Knowledge management and knowledge creation in academia: A study based on surveys in a Japanese research university. Journal of Knowledge Management, 13(2), 76-92. https://doi.org/10.1108/13673270910942718

Tien, F.F. (2008). What Kinds of Faculty Are Motivated to Perform Research by the Desire for Promotion?. Higher Education, 55, 17-32. https://doi.org/10.1007/s10734-006-9033-5

Turner, L., \& Mairesse, J. (2003). Individual productivity differences in scientific research: An econometric study of the publications of French physicists. Working Paper.

Ulrich, W., \& Dash D.P. (2013). Research skills for the future: Summary and critique of a comparative study in eight countries. Journal of Research Practice, 9(1), 1-21.

Van der Weijden, I., Belder, R., Van Arensbergen, P., \& Van den Besselaar, P. (2015). How do young tenured professors benefit from a mentor? Effects on management, motivation and performance. Higher Education, 69(2), 275-287. https://doi.org/10.1007/s10734-014-9774-5

Van der Weijden, I., de Gilderb, D., Groenewegenb, P., \& Klasenc, E. (2008). Implications of managerial control on performance of Dutch academic (bio) medical and health research groups. Research policy, 37, 1616-1629. https://doi.org/10.1016/j.respol.2008.06.007

Van Waeyenber, T., \& Decramer, A. (2018). Line managers' AMO to manage employees' performance: The route to effective and satisfying performance management. International Journal of Human Resource Management, 29(22), 3093-3114. https://doi.org/10.1080/09585192.2018.1445656

Wang, J., Peters, H.P., \& Guan, J. (2006). Factors influencing knowledge productivity in German research groups: Lessons for developing countries. Journal of Knowledge Management, 10(4), 113-126. https://doi.org/10.1108/13673270610679408

Wang, Z., \& Xu, H. (2017). How and when service-oriented high-performance work systems foster employee service performance: A test of mediating and moderating processes. Employee Relations, 39(4), 523-540. https://doi.org/10.1108/ER-07-2016-0140

White, C.S., James, K., Burke, L.A., \& Allen, R.S. (2012). What makes a research star?. Factors influencing the research productivity of business faculty. International Journal of Productivity and Performance Management, 61(6), 584-602. https://doi.org/10.1108/17410401211249175

Wollersheim, J., Lenz, A., Welpe, I.M., \& Spörrle, M. (2015). Me, myself, and my university: A multilevel analysis of individual and institutional determinants of academic performance. Journal of Business Economics, 85(3), 263-291. https://doi.org/10.1007/s11573-014-0735-3

Wright, P.M., Coff, R., \& Moliterno, T.P. (2014). Strategic Human Capital: Crossing the Great Divide. Journal of Management, 40(2), 353-370. https://doi.org/10.1177/0149206313518437

Wright, P.M., \& McMahan, G.C. (2011). Exploring human capital: putting 'human' back into strategic human resource management. Human Resource Management Journal, 21(2), 93-104. https://doi.org/10.1111/j.17488583.2010.00165.x

Zucker, L.G., Darby, M.R., Furner, J, Liu, R.C., \& Ma, H. (2007). Minerva unbound: Knowledge stocks, knowledge flows and new knowledge production. Research Policy, 36, 850-863.

https://doi.org/10.1016/j.respol.2007.02.007 


\section{Appendix}

\begin{tabular}{|c|l|c|c|c|c|c|c|c|c|c|c|}
\cline { 2 - 11 } \multicolumn{1}{|c|}{ Variables } & $\mathbf{1}$ & $\mathbf{2}$ & $\mathbf{3}$ & $\mathbf{4}$ & $\mathbf{5}$ & $\mathbf{6}$ & $\mathbf{7}$ & $\mathbf{8}$ & $\mathbf{9}$ & $\mathbf{1 0}$ \\
\hline $\mathbf{1}$ & Research abilities & 1 & -.022 & -.022 & -.022 & -.022 & -.028 & $.299^{* *}$ & .022 & -.048 & $.283^{* *}$ \\
\hline $\mathbf{2}$ & Scientific knowledge & .000 & 1 & -.022 & -.022 & -.022 & -.042 & $.208^{* *}$ & .018 & .014 & .081 \\
\hline $\mathbf{3}$ & Proactive creativity & .000 & .000 & 1 & -.022 & -.022 & -.078 & $.325^{* *}$ & -.022 & $.100^{*}$ & -.093 \\
\hline $\mathbf{4}$ & Research accuracy & .000 & .000 & .000 & 1 & -.022 & .043 & -.062 & -.099 & .024 & -.021 \\
\hline $\mathbf{5}$ & Skill of accepting criticism & .000 & .000 & .000 & .000 & 1 & -.029 & -.090 & -.011 & .065 & -.041 \\
\hline $\mathbf{6}$ & Extrinsic motivation & -.005 & -.019 & -.054 & .064 & -.006 & 1 & -.022 & .015 & .051 & -.101 \\
\hline $\mathbf{7}$ & Intrinsic motivation & $.314^{* *}$ & $.225^{* *}$ & $.340^{* *}$ & -.039 & -.066 & .000 & 1 & -.115 & .005 & .048 \\
\hline $\mathbf{8}$ & $\begin{array}{l}\text { Availability of human and } \\
\text { financial resources }\end{array}$ & .044 & .040 & .000 & -.075 & .011 & .037 & .090 & 1 & -.022 & $.206^{* *}$ \\
\hline $\mathbf{9}$ & $\begin{array}{l}\text { Availability of information } \\
\text { resources }\end{array}$ & -.025 & .036 & $.120 *$ & .045 & .086 & .072 & .027 & .000 & 1 & $.101 *$ \\
\hline $\mathbf{1 0}$ & DEA & $.299^{* *}$ & $.101 *$ & -.069 & .001 & -.018 & -.077 & .069 & $.223^{* *}$ & $.121^{*}$ & 1 \\
\hline & Marker Variable & $-.113^{*}$ & $-.146^{* *}$ & .044 & -.060 & -.054 & .029 & -.101 & $-.107 *$ & .022 & -.086 \\
\hline
\end{tabular}

Table 9. Correlations and correlations adjusted for potential common method bias

Intangible Capital, 2021 (www.intangiblecapital.org)

\section{(c) (1) $\$$}

Article's contents are provided on an Attribution-Non Commercial 4.0 Creative commons International License. Readers are allowed to copy, distribute and communicate article's contents, provided the author's and Intangible Capital's names are included. It must not be used for commercial purposes. To see the complete license contents, please visit https://creativecommons.org/licenses/by-nc/4.0/. 